\title{
Article
}

\section{Experiential learning with building craft in the architectural design studio: A pilot study exploring its implications for built heritage in the UK}

Djabarouti, Jonathan and O'Flaherty, Christopher James

Available at http://clok.uclan.ac.uk/28753/

Djabarouti, Jonathan and O'Flaherty, Christopher James (2019) Experiential learning with building craft in the architectural design studio: A pilot study exploring its implications for built heritage in the UK. Thinking Skills and Creativity, 232 . pp. 102-113. ISSN 1871-1871

It is advisable to refer to the publisher's version if you intend to cite from the work. http://dx.doi.org/10.1016/j.tsc.2019.05.003

For more information about UCLan's research in this area go to http://www.uclan.ac.uk/researchgroups/ and search for <name of research Group>.

For information about Research generally at UCLan please go to http://www.uclan.ac.uk/research/

All outputs in CLoK are protected by Intellectual Property Rights law, including Copyright law. Copyright, IPR and Moral Rights for the works on this site are retained by the individual authors and/or other copyright owners. Terms and conditions for use of this material are defined in the policies page. 
This is the final post-peer-review version of 'Experiential learning with building craft in the architectural design studio: A pilot study exploring its implications for built heritage in the UK.'. It is published in: Elsevier Thinking Skills and Creativity Volume 32, June 2019, Pages 102-113. DOI: 10.1016/j.tsc.2019.05.003

(C) 2019. This manuscript version is made available under the CC-BY-NC-ND 4.0

Title

Experiential Learning with Building Craft in the Architectural Design Studio: A Pilot Study Exploring its Implications for Built Heritage in the UK.

\author{
Authors \\ Johnathan Djabarouti MSc ARB IHBC \\ University of Central Lancashire \\ Preston, PR1 2HE, UK. \\ Christopher O'Flaherty MSc MRICS \\ University of Central Lancashire \\ Preston, PR1 2HE, UK. \\ Corresponding Author \\ Johnathan Djabarouti MSc ARB IHBC \\ j.djabarouti@mmu.ac.uk \\ 60 Henwood Rd, Manchester, M20 4XG \\ Tel: 07762759739
}




\title{
Experiential learning with building craft in the architectural design studio: A pilot study exploring its implications for built heritage in the UK.
}

\begin{abstract}
There is evidence of architectural learning being a product of both theoretical and practical knowledge, with traditional building craft being part of the original route to becoming an architect, or 'master builder'. With formalised schools of architecture emerging within the Beaux-Arts period, the educational pathway for architects distanced itself from practical 'onsite' experience, ultimately removing building craft from architectural pedagogy. This lack of experiential hands-on learning within architectural education could impact an architect's ability to deliver appropriate design solutions when working with built heritage, where the knowledge of traditional building is of great importance.
\end{abstract}

The impact of experiential learning was investigated within the architectural design studio, using a pilot study comparison experiment with two groups of architecture students. One of the groups was exposed to a hands-on building craft exercise (the other group was not) and the impact of this exposure was tested using a design task. The differences between the two groups approach to the design task were analysed using a one-way ANOVA.

The findings of the research suggest that the incorporation of experiential hands-on learning within the architectural design studio could enhance the students' ability to better understand the complexities of building materials, which in-turn could contribute towards more effective design solutions when working with built heritage. However, the process of implementing the pilot study revealed economic and logistical constraints which are perhaps reflective of the wider barriers that architectural institutions are confronted with when attempting to integrate this method of learning within the architectural design studio. 
This is the final post-peer-review version of 'Experiential learning with building craft in the architectural design studio: A pilot study exploring its implications for built heritage in the UK.'. It is published in: Elsevier Thinking Skills and Creativity Volume 32, June 2019, Pages 102-113. DOI: 10.1016/j.tsc.2019.05.003

\section{Keywords}

Architectural education; Architectural pedagogy; Heritage conservation; Experiential learning; building craft

Declarations of interest: None.

This research did not receive any specific grant from funding agencies in the public, commercial, or not-for-profit sectors. 


\section{Introduction}

Building conservation is the process of managing change to best sustain a building's significance (Historic England, 2008). This is done primarily to sustain the 'value' of built heritage for future generations, which is "central to England's cultural heritage and sense of identity" (Historic England, 2008: p 13). As architects commonly design and manage building conservation schemes, they carry a responsibility for sustaining and conserving the built heritage. This implies a professional and legal duty with regards to protected heritage assets (reflected in the Planning (Listed Buildings and Conservation Areas) Act 1990); as well as for some, a moral duty in terms of the custodianship of these assets (rooted in the philosophies of the SPAB and their manifesto of 1877). This has implications on the architectural educational system, suggesting a need for a curriculum that can give architecture students an effective prerequisite understanding of the built heritage and building conservation.

With the conservation of built heritage primarily focusing on existing structures (and thus existing materials, commonly with present defects) it is important for architects working within building conservation to have a sophisticated understanding of building materials. Although the historical evolution of architecture and its teachings is founded in both theory (thinking) and practice (doing), an understanding of 'practice' via experiential hands-on learning generally does not feature as a recommended learning model within prescribed architectural curriculum guidelines (see Royal Institute of British Architects (2014); Architect's Registration Board, n.d.). This presents a potential problem whereby architectural curricula may not be reaching its potential in preparing students (our future architects) for the complexities of working with built heritage. Within industry this could result in an overreliance on building contractors becoming the effective 'decision makers' on a built heritage scheme, owing to a designer's lack of material and craft knowledge. 


\section{Learning}

\subsection{Experiential learning theory and learning styles}

Vitruvius made a clear distinction between theoretical and practical aspects of building. In relation to the knowledge of the architect, he made reference to "knowledge that originates from the union of them, or rather the union of 'making' and 'thinking'" (Salama et al., 2002: $\mathrm{p} 43$ ). In contemporary literature, this is known as experiential learning, which is defined by Felicia (2011: p 1003) as "the process of making meaning from direct experience, namely through reflection on doing." Kolb (1984) researched the impact of experiential learning, building upon an earlier learning model by Lewin (1948). Kolb's model is known as the 'Kolb Learning Cycle'. The premise of the cycle states that effective learning occurs through real-life experiences (Kolb, 1984). He noted the work of Lewin (1948) as being of particular relevance, due to its development of a four-stage learning cycle, citing 'concrete experience' as "the basis for observation and reflection" (Kolb, 2000: p 3).

Fox and Batholomae (1999) state learning styles are unique to individuals and based on their own personal characteristics. Kolb's model (refer to Figure 1) describes four basic learning styles that are applied to the following types of learner (taken from Kolb et al. (2000)):

1. Diverging - viewing concrete situations from many different points of view.

2. Assimilating - understanding a range of information and putting into concise, logical form.

3. Converging - finding practical uses for ideas and theories.

4. Accommodating - the ability to learn from 'hands on' experience. 


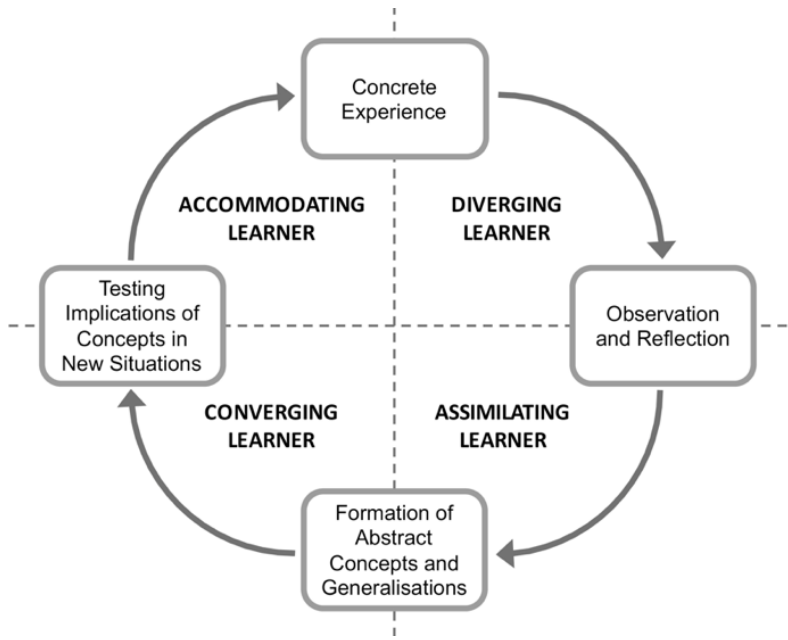

Figure 1: Kolb learning cycle with learning styles indicated next to relevant stage of the cycle.

\subsection{Architectural education}

\subsection{The relationship between theory and practice}

Historically there has been an integration of 'theory' and 'practice' within architectural design, with individuals being able to move fluidly between the two fields. We can go back as far as Vitruvius (30-15 BC), who discussed the need for a good understanding of both theory and practice. As explained in Morgan's (1914: p 11) translation of Vitruvius, "Practice is the continuous and regular exercise of employment where manual work is done with any necessary material according to the design of a drawing. Theory, on the other hand, is the ability to demonstrate and explain the productions of dexterity on the principles of proportion." Since this early departure point, the relationship between architects, theory and practice has varied substantially, often being reflective of societal class conditions based on "the division of minds and bodies, mental and manual work, and clean and dirty work." (Thiel, 2007: p 228). Wieringa (2004: p 2) states that "since Roman times, handwork was looked down upon by intellectuals. Vitruvius tries to give the architect more status by emphasising the need for theoretical knowledge." Ultimately, this divide was created and sustained by slave-owning culture, which reinforced thinking as an activity for free-born men and manual work with slavery (Ayres, 1998: p 8). 
This perspective transformed during medieval Europe, out of which grew the 'master' (be that the master builder, master mason, or master architect) - hereafter referred to as 'master builder'. This term identified an individual who was highly experienced in the art of building, having amassed a variety of construction and material knowledge via the 'guild system' of training; from 'apprenticing', through to 'journeyman', and finally 'master' (Jacobs, 1970). The master builder, having gained experience through physical hands-on training, was at the peak of practical building knowledge. Apprentices would often start as labourers; become layers; then possibly carvers of fine stone. Finally, if the apprenticeship was seen to have potential, they would apprentice with the master mason and learn design techniques (Ousterhout, 2008). It is this manual, tactile aspect of learning how to design and construct buildings that can make building craft a useful pedagogic vehicle for architects, whose profession exists primarily as a conceptual activity in contemporary society (Christensen, 2008). In this sense, the design process naturally precedes the existence of the physical entity that is being designed.

\subsection{Course validation criteria}

The formalised teaching of architecture in the UK as we know it today has a comparatively limited history, in that the professional institution itself (the Royal Institute of British Architects (RIBA)) was only established in 1884 (Crinson, 1994) at the height of the BeauxArts movement in France. This establishment of an architectural profession only fuelled the steady separation that was occurring between theory and practice since the Age of Reason (Ayres, 1998). The RIBA, through its architectural educational pathway, allowed the education and development of an architect to occur off-site, sidestepping the original migration "from apprentice to master craftsmen to builder/ architect" (Ayres, 1998: p 9). In the Twenty-First Century, this historical loss of on-site training has removed real construction scenarios and materials from architectural education and fortified a 'theory-led' approach to architecture, which instead uses a variety of representational artefacts at various stages of the design process (Christensen, 2008).

Practicing architects can be involved in a variety of building projects at a variety of stages, from helping clients define a brief, through to more technical constructional strategies. To 
give building design a more refined framework, the 'RIBA Plan of Work' was developed in 1963 and is still in use today (last revised in 2013). The RIBA describe the Plan of Work as "a shared framework for the organisation and management of building projects that is widely used as both a process map and a management tool." (RIBA, 2013: p 2). For the rest of the construction industry, the RIBA Plan of Work is useful as a definition of reference points for contractual and appointment obligations; but for architects it is also a reference point for what skills and knowledge will be required at particular stages of the design process. For example, RIBA Stage 0 (Strategic Definition) represents the identification of client briefs and project requirements, which will require a completely different skill set to RIBA Stage 3 (Developed Design), which represents the completion of a coordinated design, including costings.

Two sets of criteria govern architectural education within a university setting. The first, developed by the ARB, is the 'Prescription of Qualification ARB Criteria at Parts 1, 2 and 3'. This document describes "the subject material that must be covered by students gaining qualifications that are prescribed by ARB at Part 1 and Part 2 levels" (Architects Registration Board, n.d.). Secondly, there is the 'Royal Institute of British Architects Procedures for Validation and Validation Criteria'. The validation criteria within this document provides a "basis for curricular design" (Royal Institute of British Architects, 2014: p 57). As Salama et al. (2002) highlighted, there are several sources that indicate disagreements over what is meant by 'architecture' and 'design'. They explain this has naturally led to significant diversity of course content and teaching methods across institutions. This does not appear to be problematic for the RIBA (2014: p 14) who encourage schools to "creatively capture the uniqueness of their academic offer and student experience." 
This is the final post-peer-review version of 'Experiential learning with building craft in the architectural design studio: A pilot study exploring its implications for built heritage in the UK.'. It is published in: Elsevier

Thinking Skills and Creativity Volume 32, June 2019, Pages 102-113. DOI: 10.1016/j.tsc.2019.05.003

\begin{tabular}{|c|c|c|}
\hline Code & Criteria & Key words \\
\hline GC1 & $\begin{array}{l}\text { Ability to create architectural designs that satisfy both aesthetic and } \\
\text { technical requirements }\end{array}$ & $\begin{array}{l}\text { Design, aesthetic, } \\
\text { technical }\end{array}$ \\
\hline GC2 & $\begin{array}{l}\text { Adequate knowledge of the histories and theories of architecture and the } \\
\text { related arts, technologies and humanities }\end{array}$ & $\begin{array}{l}\text { History, theory, } \\
\text { humanities, art, } \\
\text { technology }\end{array}$ \\
\hline GC3 & $\begin{array}{l}\text { Knowledge of the fine arts as an influence on the quality of architectural } \\
\text { design }\end{array}$ & Fine art, design \\
\hline GC4 & $\begin{array}{l}\text { Adequate knowledge of urban design, planning and the skills involved in } \\
\text { the planning process }\end{array}$ & $\begin{array}{l}\text { Urban design, } \\
\text { planning }\end{array}$ \\
\hline GC5 & $\begin{array}{l}\text { Understanding of the relationship between people and buildings, and } \\
\text { between buildings and their environment, and the need to relate buildings } \\
\text { and the spaces between them to human needs and scale }\end{array}$ & $\begin{array}{l}\text { People, society, } \\
\text { environment, } \\
\text { space, scale }\end{array}$ \\
\hline GC6 & $\begin{array}{l}\text { Understanding of the profession and the role of the architect in society, in } \\
\text { particular in preparing briefs that take account of social factors }\end{array}$ & $\begin{array}{l}\text { Profession, societal } \\
\text { Factors, brief } \\
\text { preparation }\end{array}$ \\
\hline GC7 & $\begin{array}{l}\text { Understanding of the methods of investigation and preparation of the brief } \\
\text { for a design project }\end{array}$ & Brief preparation \\
\hline GC8 & $\begin{array}{l}\text { Understanding of the structural design, constructional and engineering } \\
\text { problems associated with building design }\end{array}$ & $\begin{array}{l}\text { Structures, } \\
\text { construction, } \\
\text { engineering }\end{array}$ \\
\hline GC9 & $\begin{array}{l}\text { Adequate knowledge of physical problems and technologies and the } \\
\text { function of buildings so as to provide them with internal conditions and } \\
\text { protection against the climate }\end{array}$ & $\begin{array}{l}\text { Technology, } \\
\text { function, cost, } \\
\text { climate }\end{array}$ \\
\hline GC10 & $\begin{array}{l}\text { The necessary design skills to meet building users' requirements within } \\
\text { the constraints imposed by cost factors and building regulations }\end{array}$ & $\begin{array}{l}\text { Cost, building } \\
\text { regulations }\end{array}$ \\
\hline GC11 & $\begin{array}{l}\text { Adequate knowledge of the industries, organisations, regulations and } \\
\text { procedures involved in translating design concepts into buildings and } \\
\text { integrating plans into overall planning }\end{array}$ & $\begin{array}{l}\text { General industry } \\
\text { knowledge }\end{array}$ \\
\hline
\end{tabular}

Table 1: RIBA and ARB criteria for validation and course prescription. 
As of 2015 there were 44 validated schools of architecture (RIBA, 2011-2015) that can all provide their own unique interpretation of the validation criteria. This allows for a broad spectrum of architectural education and could therefore contribute towards architecture students graduating with a broad range of skills and interests that could be applicable to many professions - not exclusively architecture. Both the ARB and RIBA criteria include the same content (Table 1 provides a list of 11 coded criteria that make up the requirements of both bodies). When appending key words against each criterion, general overlaps can be seen and a more concise flavour of the requirements set by the ARB and RIBA can be further reduced to a list of 9 'learning topics' (refer to Table 2).

\begin{tabular}{lll}
\hline No. & Criteria Learning Topic & ARB/ RIBA Relevant Codes \\
\hline 1 & Art \& Design & GC1, GC3 \\
\hline 2 & Technology & GC1, GC2, GC9 \\
\hline 3 & Humanities (History \& Theory) & GC2 \\
\hline 4 & Urban Design \& Planning & GC4, GC5, GC11 \\
\hline 5 & Brief Preparation & GC6, GC7 \\
\hline 6 & Construction \& Engineering & GC8, GC11 \\
\hline 7 & Cost & GC9, GC10 \\
\hline 8 & Building Regulations & GC10, GC11 \\
\hline
\end{tabular}

Table 2: Summary of learning topics extracted from RIBA and ARB criteria. Practical building craft activities would compliment or enhance many of the codes, including GC1, GC2, GC3, GC7, GC9.

Roberts (2006) states the main pedagogic vehicle for carrying out these learning topics within architectural education is project-based learning (generally called 'design studio' in the UK). He goes on to explain that "unlike education in some other disciplines, design project work [design studio] does not seek a single correct answer; rather the student is invited to make propositions which are often speculative and exploratory in nature." (2006: p 168). Schools of architecture are therefore not only made up of distinctive interpretations of the curriculum by universities (Salama et al., 2002) (RIBA, 2014); but also distinctive explorations of the curriculum(s) by the students (Roberts, 2006). In theory, this creates a flexible framework which could support the use of experiential hands-on learning via building craft to aid in the student's understanding of built heritage. Yet, as this does not feature as a prescriptive part of the validation criteria, its use and potential effectiveness within prescribed architecture courses in the UK is hard to define and measure. Nonetheless, it is evident that a lack of 
experiential hands-on learning in architectural education could be detrimental to those students who are 'Accommodating Learners', due to their dominant learning abilities being concrete experience and active experimentation (Kolb et al., 2000).

\subsection{Experiential possibilities within the architectural design studio}

Salama (2010: p 293) states that active and experiential learning within architectural education is not only a frontier in architectural pedagogy but is also a critical component that can link the hypothetical aspects of an architecture course with the realities of the profession. With this in mind, it is interesting to note that architectural design studio pedagogy has developed very little since 1985 (Webster, 2004: p 105). Although there are studies that clearly contribute to questioning the nature and approach of architectural education (such as Demirbas and Demirkan (2003) and Kvan and Yunyan (2005), both of which use Kolb's (1984) model to correlate student learning styles against the design process and performance in design studio; these studies focus primarily on interpreting the complexities created by different learning styles within architectural education, rather than experimenting with specific pedagogic interventions within an architectural design studio environment.

Salama's (2010) study provides a form of experimental intervention which builds on a traditional 'taught' format. It proposes specific interactive exercises within architectural education that utilised images and text as tools to encourage interactive learning and critical thinking (2010: p 283). Whilst Salama's approach clearly breaks the traditional pedagogic format of a typical 'taught' session, Gore's (2004) 'hands-on' craft-based approach is arguably more geared towards the understanding of specific building materials - their role; properties; functions and limitations - providing a more direct connection between the student and the phenomenon of building.

Regardless of the learning style and type of learner, 'failure' is seen as a fundamental aspect of the learning cycle, and more particularly as part of the reflective process (refer to Figure 2). As DeGregori and Matson discussed in Sitkin (1992), repetition does not produce evolutionary change without unplanned error in the procedure. Therefore, within the learning cycle, failure is necessary during 'practice' so individuals can interrogate their errors during 'reflection'. In turn, this leads to individuals developing better skills for the next iteration of 
this particular experience. Essentially, this is how 'practice' works. As Kolb (1984: p 29) testifies, "I am occasionally upended by unforeseen circumstances, miscommunications, and dreadful miscalculations. It is in this interplay between expectation and experience that learning occurs."

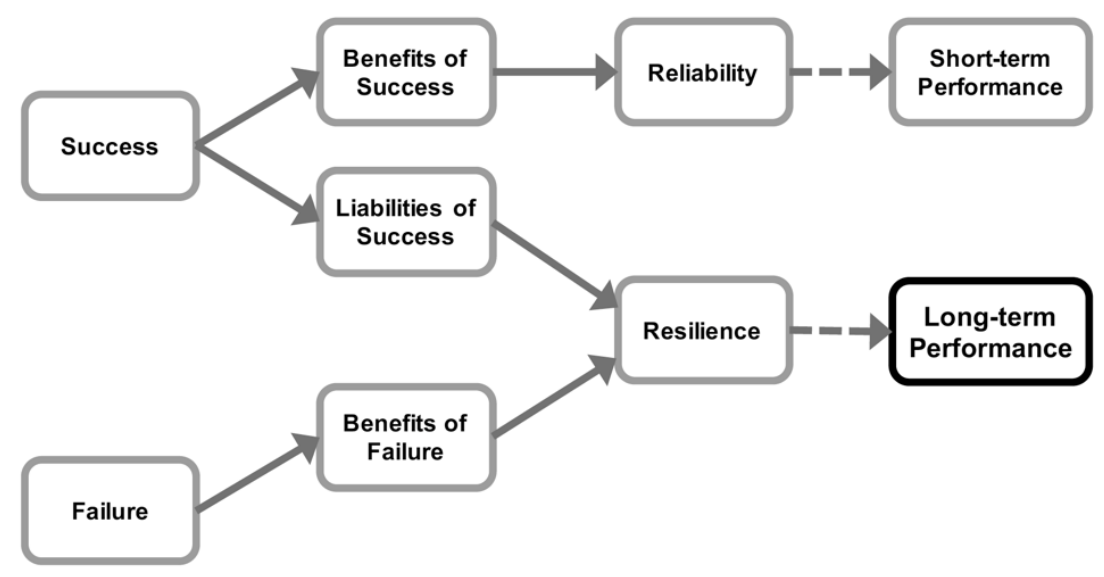

Figure 2: The benefits and liabilities of success and failure (Sitkin, 1992).

The 'design studio' is a pedagogic arena that has the potential to integrate craft and materials into the design process (Gore, 2004). Within this space, Roberts explained students can be exploratory in their response to a brief, rather than searching for a single correct answer. It is possible that the integration of building craft could support the notions of 'learning through failure' (Sitkin, 1992) and 'trial and error' (Kolb, 1984) - promoting more iterative and reflective approaches to design. From this perspective, building craft could be a 'supplemental enabler' that can bring the realities of architecture into the design studio, which is by nature free from the pressures and risks of professional practice (Schon, 1987). Carpenter (1997) proposed the 'design studio' could be superseded by an environment which promoted learning through building (Carpenter, 1997: p 28). Named the 'construction studio', he stated this would address two primary criticisms of architectural education: 1) its inability to teach students about the practical aspects of design; and 2) the insular/inward looking nature of schools of architecture. Whilst a construction studio would certainly encourage more practical activities within architectural education, there would be clear 
financial and logistical barriers for many institutions surrounding the implementation of the construction studio.

Salama et al. (2002: p 101) states experiential learning in architecture can be "the discipline in which the learner makes direct contact with the realities being studied either inside or outside the classroom." This is of particular importance to those architectural students who wish to work with built heritage, as those existing buildings are not conceptual - they are fixed realities of the historic built environment which can be analysed, interpreted and understood. The integration of craft within the architectural design studio is one way to increase connection to those fixed realities, by reducing the amount of 'representational artefacts' (Christensen, 2008) in place of real materials, which will better encourage an evaluation of things for what they are - rather than for how well they represent something else in the 'real world' (Gore, 2004). Through a series of project examples, Gore (2004) uses the notion of 'serious play' to explore an alternative way of working for architecture students. Whilst his work highlights the ability for craft to provoke a level of agency and selfconfidence in a student's ability to generate 'mastery' over a project, the suggested positive impact of this alternative way of learning was not quantitively tested or measured. Nonetheless, the study provokes a level of inquiry as to how the integration of experiential hands-on learning into the architectural curriculum could impact the successful future delivery of a built heritage project.

\subsection{Research problem}

The experience of architectural education in most universities (in particular its 'design studio' element) is more a 'virtual world' consisting of 'representational artefacts', which does not have to accommodate the stresses or dangers of the real world (Schon, 1987; Christensen, 2008). Roberts (2006: p 168) suggests a healthy mix between theory and practice is the most beneficial approach for architecture students to become "well rounded, competent and imaginative designers of buildings and the spaces between them"; yet more experiential hands-on approaches to learning within the architectural design studio - such as those championed by Carpenter (1997) and Gore (2004) - are understudied in terms of statistically 
quantifying the impact of this way of learning, both on the students and the resultant design quality.

This pilot study is interested in facilitating architecture students with the abilities needed to work with built heritage, as this role requires a specialist knowledge of traditional building materials. Furthermore, as architecture and building conservation continuously evolve, it is vital that existing teaching and learning models are questioned and new learning models are tested in order to keep up with the demands of the heritage sector. By attempting to measure the impact of experiential hands-on learning using an experiment, we can assess not only how this pedagogic change could impact architectural education but also how realistic this method of learning is to integrate within architectural design studio.

\subsection{Empirical research}

\subsection{Experiment validity}

This pilot study explored whether an experiment is an appropriate means of testing the impact of experiential hands-on learning within the architectural design studio. The completion of this pilot study experiment establishes whether the experimental approach is a potential way to progress the research, ensuring that in addition to any data produced, the actual experimental process itself is observed and evaluated.

In particular, the experiment builds on notions within the literature that suggest experiential hands-on learning can be beneficial to architecture students. It seeks to explore in what capacity and to what extent these benefits can be quantified, as well as exploring in tandem what the potential disadvantages/ limitations may be when integrating this learning approach, as these are generally not discussed or evaluated within the literature.

\subsection{Participants}

As the context of the research objective was the architectural pedagogic environment, the overall target sample was architecture students based at a UK institution. A random sampling procedure was used, targeting all students at a local School of Architecture (from first year BA(hons) students through to final year MArch students). The sample size was limited due to 
a number of practical limitations posed by the 'hands-on' craft nature of the experiment. The factors impacting the sample size were: a) the financial cost of purchasing and hiring the craft tools and materials for the pilot study; b) the space per participant that was required to carry out the experiment; and c) the logistics of transporting the craft tools and materials. The final sample size was 10 architecture students (5 students per group), ranging from first year BA(hons) Architecture to final year MArch students.

This small sample size naturally poses significant limitations and potential flaws with regards to the validity of the experimental data. Prior to beginning the experiment, the likelihood of a Type II Error was calculated based on the final sample size. Based on $n=10 ; p=0.05$ and a predicted effect size (Cohen's d) of 0.5, the Beta level predicted for the experiment was 0.82 . This is significantly higher than the proposed maximum accepted probability of a Type II error of 20\% $($ Beta $=0.2)($ Cohen, 1998). This further illustrates that any results from this pilot study will be preliminary but nonetheless will contribute towards the direction of further, more robust research within this field.

\subsection{Design experiment}

An experiment was designed and conducted to test the impact of experiential hands-on learning on design quality via a hands-on stone masonry craft exercise (refer to Figure 3 for experiment overview). The experiment was designed to merge more typical representational artefacts within architectural design (Christensen, 2008) with a hands-on craft experience similar to Gore's 'serious play' concept (potentially unlocking the students critical thinking towards architectural design) (Gore, 2004).

The first part of the experiment was a 'pre-test', designed to eliminate any knowledge bias within the results by allowing this to be controlled within the analysis. The pre-test was a simple quantitative survey that asked students to rate their own experience and knowledge within three categories: architecture; building conservation and the craft of stone masonry (refer to Section 5.0 for pre-test results).

Following the pre-test, each group watched an identical 30-minute 'instructional video' of a master stone mason demonstrating the principles of creating a flat surface on a piece of 
natural stone (refer to Figure 4). The chosen stone mason had over 30 years' experience and was the President of the Master Carver's Association. He also had previous experience teaching his craft to groups of both students and hobbyists. The stone mason communicated instructions through verbal guidance, whilst physically demonstrating the process and technique required to achieve the end result. The instructional video was designed, recorded and edited solely for the purpose of the research project, with recording taking place at the stone mason's workshop (refer to Figure 5).

After watching the video, Group 1 participants only (comprising 5 of the 10 participants, defined as the 'test group') were given a rough piece of lime stone and all the craft tools used within the instructional video. The test group were then given $90 \mathrm{~min}$ to try and reproduce what they had witnessed in the video, the aim being to form a flat tooled face on the stone using only the tools provided and without any help or guidance. Students did not receive any guidance or coaching during this period but were free to talk amongst themselves, as is typical within an architectural design studio (refer to Figure 6). Following this exercise, both groups completed an identical 'design test'. The aim of this test was to assess what the students had learned either from watching the video and performing the craft exercise; or solely though watching the video. The design test is explained below.

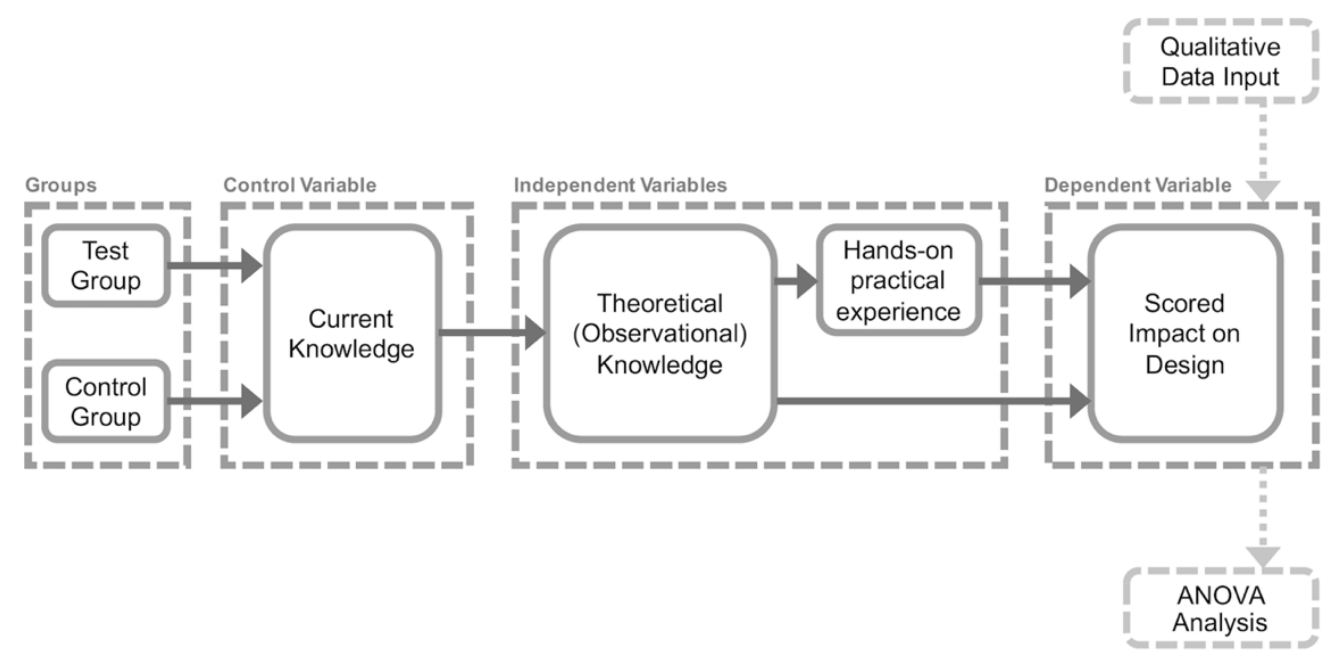

Figure 3: Theoretical design overview of experiment. 
This is the final post-peer-review version of 'Experiential learning with building craft in the architectural design studio: A pilot study exploring its implications for built heritage in the UK.'. It is published in: Elsevier Thinking Skills and Creativity Volume 32, June 2019, Pages 102-113. DOI: 10.1016/j.tsc.2019.05.003
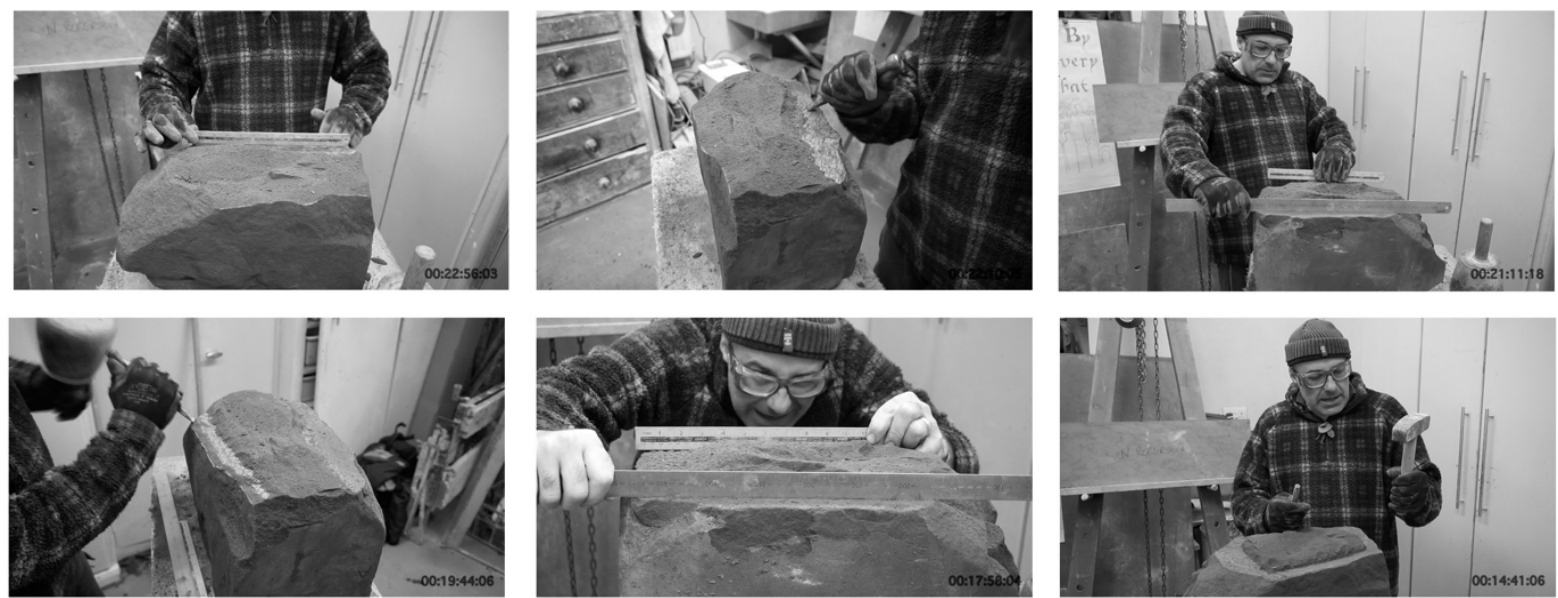

Figure 4: Stills from instructional video, showing stages of the process (Nick Roberson of Roberson Stone Carving (robersonstonecarving.co.uk)).

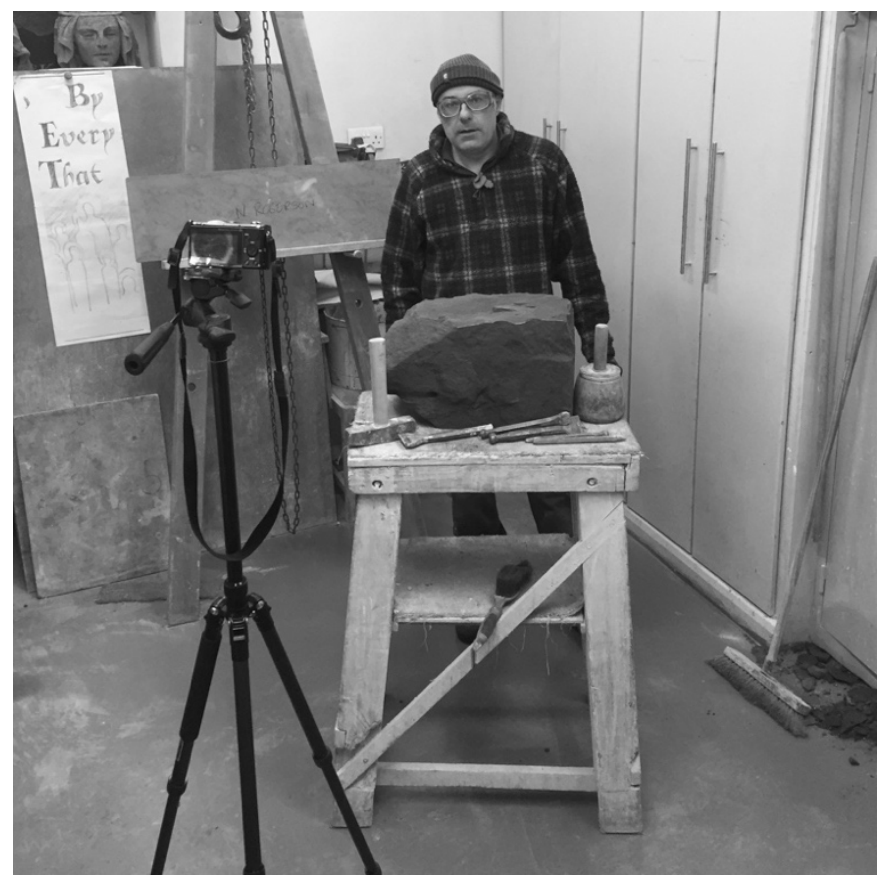

Figure 5: Filming setup for the experiment instructional video, with stone carver and mason Nick Roberson, of Nick Roberson Stone Carving (robersonstonecarving.co.uk). 


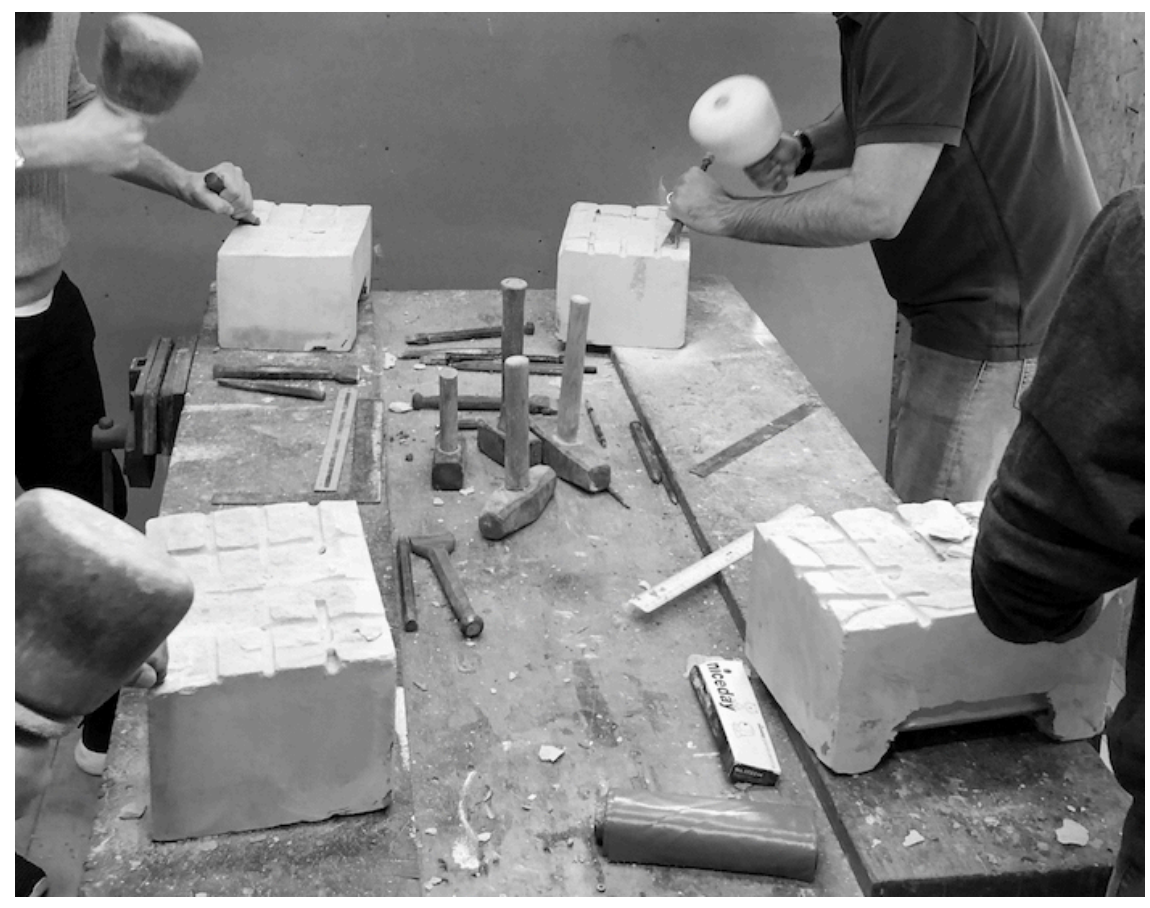

Figure 6: Test group participants using traditional tools and materials to carry out the 'hands-on' task. Students were free to engage with one another during the task but received no guidance or coaching from anyone else.

\subsubsection{Design test}

The pilot study consisted of a small sample size with significant limitations. During the design of the experiment, it was decided to investigate opportunities for quantitative assessment of the data produced by the students. The chosen method for evaluation was the integration of a set of scoring criteria within a design test to understand how the level of each participants learning within the two groups could be measured after completing the experiment. In particular, the research was interested in understanding where any potential barriers or limitations were in attempting to quantify the impact of experiential hands-on learning.

The context of the design test was based around a fictitious narrative of each participant being approached by a hobbyist client who had designed their own natural stone porch for their house. The participants were asked by the client to review the drawings they had produced for the natural stone porch and provide their comments/ feedback on the technical 
success of the design, via hand mark-ups on the drawings. Alongside the design drawings, the design test also included a series of multiple-choice questions (posed as client queries) for the participants to answer.

\subsubsection{Establishing design deficiencies}

A set of scoring criteria was integrated within both the design drawings and accompanying multiple-choice questions, to enable comparative scoring between the two groups. The criteria was developed from two sources: 1) the stone mason's instructional video, which revealed a number of common mistakes or misconceptions made by architects in relation to designing with natural stone (refer to Table 4); and 2) a small-scale qualitative survey to stone masons in the North of England questioning what they felt an architect's typical gaps in knowledge were when designing with natural stone (refer to Table 3). The information extracted from these two sources was thematically analysed and consolidated into a total of 8 'deficiency categories'. Each deficiency was assigned a code and embedded within the design test information (client design drawings and client queries). For example, Deficiency D1 (Pastoral) was embedded within the 'client queries' (multiple-choice questions) part of the design test by asking whether the input and advice from a stone mason was required; Deficiency D2 (Physical) was embedded within the design drawings by incorrectly sizing the stonework into unachievable shapes and modules. 
This is the final post-peer-review version of 'Experiential learning with building craft in the architectural design studio: A pilot study exploring its implications for built heritage in the UK.'. It is published in: Elsevier Thinking Skills and Creativity Volume 32, June 2019, Pages 102-113. DOI: 10.1016/j.tsc.2019.05.003

\begin{tabular}{|c|c|c|c|}
\hline \multicolumn{4}{|c|}{$\begin{array}{l}\text { Architect deficiencies when working with natural stone } \\
\text { (Stone mason survey themes) }\end{array}$} \\
\hline $\begin{array}{l}\text { Deficiency } \\
\text { Code }\end{array}$ & $\begin{array}{l}\text { Deficiency } \\
\text { Title }\end{array}$ & $\begin{array}{l}\text { Deficiency } \\
\text { Description }\end{array}$ & $\begin{array}{l}\text { Deficiency Location } \\
\text { in Design Test }\end{array}$ \\
\hline D1 & Pastoral & $\begin{array}{l}\text { Architects do not want or feel the need } \\
\text { to communicate or seek guidance from } \\
\text { stone masons regarding natural stone } \\
\text { building designs. }\end{array}$ & $\begin{array}{l}\text { Client Queries } \\
\text { (multiple-choice) }\end{array}$ \\
\hline D2 & Physical & $\begin{array}{l}\text { Architects do not appreciate the } \\
\text { physical constraints of natural stone } \\
\text { e.g. availability of sizes, fragility of } \\
\text { different stone types. }\end{array}$ & Client design drawings \\
\hline D3 & Performance & $\begin{array}{l}\text { Architects do not put enough research } \\
\text { into the properties of stone e.g. } \\
\text { porosity, compressive strength, } \\
\text { orientation of 'bed'. }\end{array}$ & Client design drawings \\
\hline D4 & Precipitation & $\begin{array}{l}\text { Water management is generally not } \\
\text { given high priority within natural stone } \\
\text { building design anymore, due to } \\
\text { aesthetic trends, leading to unnecessary } \\
\text { long-term deficiencies. }\end{array}$ & Client design drawings \\
\hline
\end{tabular}

Table 3: Deficiencies extracted from the small-scale stone masonry survey.

\begin{tabular}{llll}
\hline Deficiency & \multicolumn{1}{c}{$\begin{array}{c}\text { Architect deficiencies when working with natural stone } \\
\text { (Stone masonry instructional video themes) }\end{array}$} \\
\hline Code & $\begin{array}{l}\text { Deficiency } \\
\text { Title }\end{array}$ & $\begin{array}{l}\text { Deficiency } \\
\text { Description }\end{array}$ & $\begin{array}{l}\text { Deficiency Location } \\
\text { in Design Test }\end{array}$ \\
\hline D5 & Unpredictability & $\begin{array}{l}\text { The instructional video makes many } \\
\text { references to the unpredictability of } \\
\text { natural stone }\end{array}$ & Client design drawings \\
D6 & Tolerance & $\begin{array}{l}\text { A tolerance should be incorporated } \\
\text { within the design and crafting of } \\
\text { natural stone }\end{array}$ & $\begin{array}{l}\text { Client Queries } \\
\text { (multiple-choice) }\end{array}$ \\
\hline D7 & Time & $\begin{array}{l}\text { The process of working with natural } \\
\text { materials is slow, time consuming } \\
\text { and requires multiple 'passes' }\end{array}$ & $\begin{array}{l}\text { Client Queries } \\
\text { (multiple-choice) }\end{array}$ \\
\hline D8 & Irreversibility & $\begin{array}{l}\text { The irreversible nature of working } \\
\text { with natural materials means small } \\
\text { mistakes can be costly }\end{array}$ & $\begin{array}{l}\text { Client Queries } \\
\text { (multiple-choice) }\end{array}$ \\
\hline
\end{tabular}

Table 4: Deficiencies extracted from the stone masonry instructional video. 
Participants answered the multiple-choice questions and produced hand mark-ups over the drawings. The nature of these hand mark-ups varied, with some participants writing annotations/ comments; some requesting further information (such as dimensions); some attempting to re-draw unachievable details more realistically; and others using more diagrammatic 3D sketching to communicate their comments (refer to Figure 7).

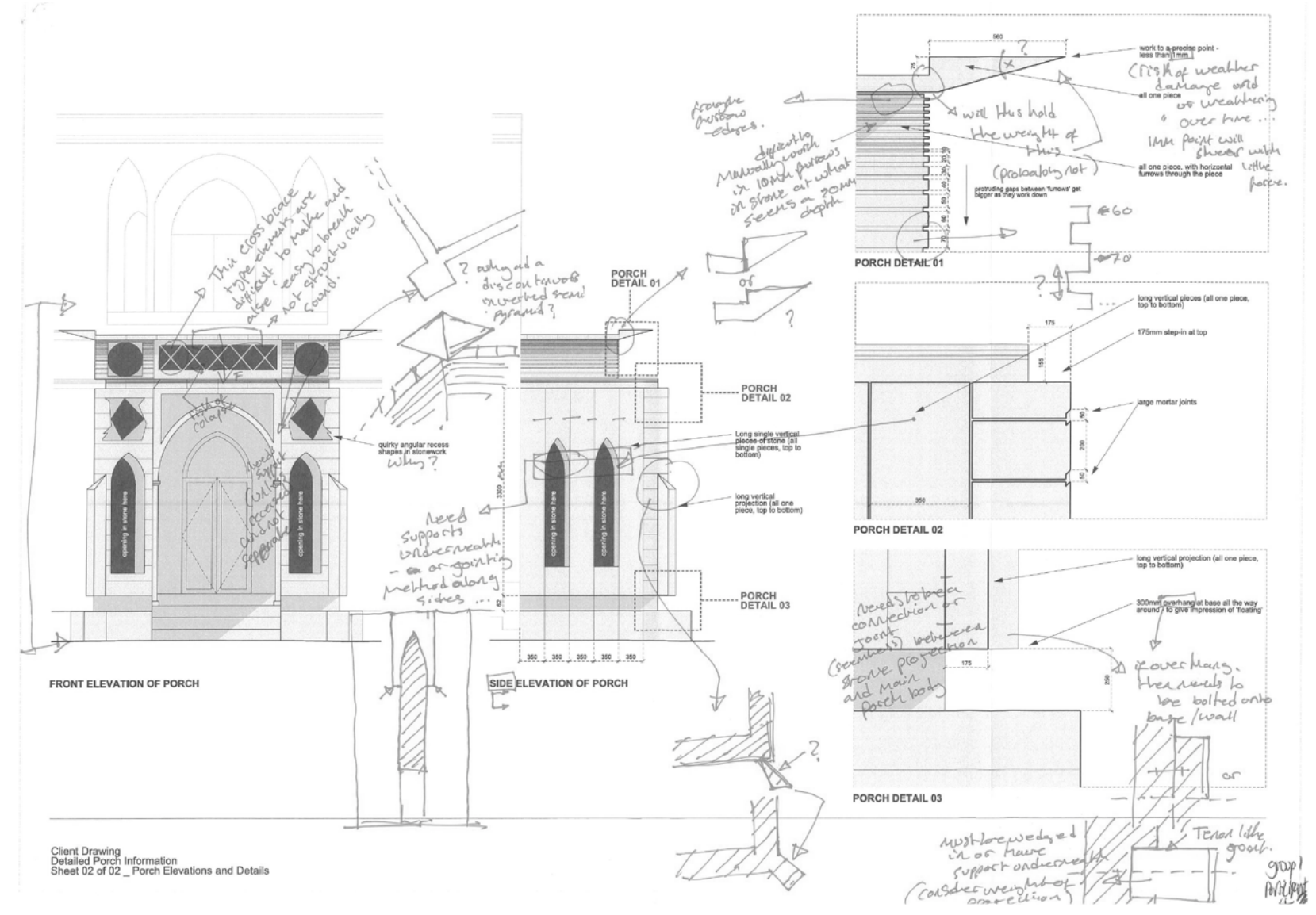

Figure 7: Group 1 participant mark-ups of the design test client drawings.

\subsection{Results}

In order to understand whether there was a need to control for a participant's prior understanding of architecture, craft and building conservation, a correlation was ran between pre-test scores and deficiency scores. No correlation was found, $(\mathrm{r}(10)=.31, \mathrm{p}=.39)$, 
therefore no covariate was used for the analysis of the experiment. This led to the conclusion that data should be analysed using ANOVA (refer to Table 5).

\begin{tabular}{llr}
\hline & & $\begin{array}{r}\text { Pre-test } \\
\text { Score Tot. }\end{array}$ \\
\hline \multirow{3}{*}{ Deficiency Score } & Pearson Correlation & .308 \\
\cline { 2 - 3 } & Sig. (2-tailed) & .386 \\
\cline { 2 - 3 } & $\mathrm{N}$ & 10 \\
\hline
\end{tabular}

Table 5: Correlation analysis between participant 'pre-test survey' results and participant 'deficiency score' results.

In trying to develop an understanding of the potential validity of the pilot study as a method to test the impact of the experiential hands-on learning intervention, the differences between the test group and control group were compared in a variety of ways, as follows:

- Overall group deficiency scores (multiple-choice 'client queries' and 'client design drawings' combined).

- Overall group multiple-choice client queries only

- Overall group client design drawings only

- Group scores for each of the 8 individual deficiencies, as follows:
○ Code D1 - Pastoral
- Code D2 - Physical
- Code D3 - Performance
- Code D4 - Precipitation
- Code D5 - Unpredictability
- Code D6 - Tolerance
- Code D7 - Time
- Code D8 - Irreversibility

There was no significant difference found between the two groups when comparing the overall group deficiency scores, $(\mathrm{F}(1,7)=.453, \mathrm{p}=.523)$. However, a significant difference between groups was found for the responses to the client design drawings, $(F(1,8)=6.00, p$ $=.040)$. A significant difference was also measured between the two groups for two of the 
eight individual deficiencies: client query 1 (multiple-choice question) (Deficiency D1 Pastoral), $(\mathrm{F}(1,8)=6.00, \mathrm{p}=.040)$; and client design drawing (Deficiency D4 Precipitation $),((1,8)=16.00, \mathrm{p}=.004)$.

Cohen (1988) stated the 'effect size' (Eta squared value) can be measured by comparing against the following size range:

- Small Eta $=0.2$

- Medium $\operatorname{Eta}=0.5$

- Large $\quad$ Eta $=0.8$

Based on this scale, all three variables which demonstrated a 'significant difference' are within the 'medium effect' range $($ Eta $=0.429$ up to Eta $=0.667)($ refer to Table 6$)$.

\begin{tabular}{lllll}
\hline Variable & Deficiency Code & Group 1 & Group 2 & Eta Squared \\
\hline Design Test Q1 & D1 - Pastoral & 3.4 & 4.0 & 0.429 \\
\hline $\begin{array}{l}\text { Design Test } \\
\text { Design Drawings }\end{array}$ & D4 - Precipitation & 0.8 & 0.0 & 0.667 \\
\hline & D2 - Physical & & & \\
$\begin{array}{l}\text { Combined Design } \\
\text { Drawings Results }\end{array}$ & $\begin{array}{l}\text { D4 - Precipitation } \\
\text { D5 - Unpredictability }\end{array}$ & 3.0 & 1.8 & 0.429 \\
& & & \\
\hline
\end{tabular}

Table 6: Three variables that indicated a significant difference between test groups, and their effect size.

\subsection{Discussion}

\subsection{Overall}

There was no significant difference found between the overall deficiency scores of the two groups. This was unsurprising due to the small sample size which resulted in an increased predicted likelihood of a Type II Error. There was however a significant difference between experiment test groups specifically for their mark-ups on the client's design drawings. This indicates a possibility that the experiential hands-on learning task had a positive impact on test group participant's abilities to improve design quality. A significant difference was also 
specifically measured for two of the individual deficiencies; Deficiency D1 (Pastoral) and D4 (Precipitation).

\subsection{Pastoral}

The pastoral deficiency was derived from the stone masonry survey source and was relating to the perception from stone mason's that architects do not want or feel the need to communicate, meet, or seek guidance from them when designing with natural stone. The significant difference for this deficiency indicates that the experiential hands-on learning task allowed the test group to better understand the complexities involved in working with natural stone and thus were more inclined to seek the advice/ guidance of an experienced craftsperson. This would not only be beneficial to a built heritage project but also to the relationship between architects and craftspeople, as it helps further break down any historical stigma relating to the negative perception of craft (handwork) (Wieringa, 2004). It could also contribute towards satisfying criteria GC1 (design, aesthetic, technical); GC7 (brief preparation); and GC11 (general industry knowledge) within the aforementioned RIBA (2013) and ARB (nd.) criteria.

\subsection{Precipitation}

The second deficiency which measured a significant difference was 'precipitation'. This was again derived from the stone masonry survey and was regarding the opinion from stone masons that architects do not put enough research into the scientific properties of stone (e.g. porosity, compressive strength, orientation of the 'bed'). The significant difference for this deficiency indicates that after the experiential hands-on learning task, the test group were more in tune with the inherent defects of natural stone and were therefore more conscious of ensuring the design was detailed in such a manner to avoid issues arising specifically from precipitation. For architects, an enhanced appreciation of the factors that can negatively impact building materials (defects) is critical, particularly within a built heritage scheme. This can satisfy criteria GC1 (design, aesthetic, technical) and GC9 (technology, function, cost, climate) within the aforementioned RIBA (2013) and ARB (nd.) criteria. 


\subsection{Other contributory factors}

There were a number of other possible contributory factors to the results of the experiment. Firstly, the test group had 90 min more exposure to learning, as they not only completed the theoretical (observational) knowledge but also practical hands-on experience as well. Secondly, it is uncertain as to whether the experiment results were influenced by the Hawthorne Effect, as it is certainly possible that the 'novelty' factor and general rarity of the hands-on stone masonry experience within the architectural design studio could have raised excitement levels. Whilst the author acknowledges research that questions the credibility of the Hawthorne Effect (Prince, 2004: p 224; Bracey, 2002: p 642), it is possible that this could have had impact on the results.

\section{Conclusion}

The aim of this pilot study was to investigate the impact of experiential hands-on learning when undertaken within the architectural design studio and to recognise how its potential integration within the architectural curricula may help students make better design decisions when working with built heritage. The impact was measured not just in quantitative realterms in relation to the results from the experiment, but also in terms of the research practicalities and limitations surrounding the integration of this learning method within the architectural studio.

The results from the experiment demonstrated that the integration of experiential hands-on learning via building craft within the architectural design studio does have the capacity to make a significant impact on design quality, which is a fundamental 'taught' aspect of architectural education. It has potential to do this by giving architecture students an enhanced material understanding concerning the physicality, performance and unpredictability of natural materials, as well as enhancing considerations for potential material defects. The integration of hands-on craft practice within the architectural design studio would also allow for a more even distribution of learning styles within architectural education, giving a fairer selection of learning methodologies for students who all innately have preferred learning styles. 
Further research should seek to not only examine the day-to-day barriers and limitations of teaching in this way (perhaps via qualitative surveys with architecture tutors); but to also improve upon the validity of this experiment by increasing the sample size. Based on the observed effect size from this pilot study (Cohen's $d=0.453$ ), the sample size for any future study would need to be at least $\mathrm{n}=122$ in order to comply with the accepted $20 \%$ probability of a Type II Error (Cohen, 1998).

Overall, whilst the results from this pilot study are encouraging, the sample size for the experiment was low (10 participants), which naturally reduces the reliability of the results. Interestingly, the economic and logistical constraints dictating the low sample size of the experiment are perhaps reflective of the wider barriers and limitations that architectural institutions are confronted with, when attempting to integrate experiential hands-on learning using craft within the architectural design studio.

\section{References}

Architects Registration Board (n.d.). Prescription of qualifications: ARB criteria at parts 1, 2 and 3. London: ARB

Ayres, J. (1998). Building the Georgian city. New Haven: Published for the Paul Mellon Center for Studies in British by Yale University Press.

Bracey, G.W. (2002) Research - tips for readers of research: Beware the 'classic study'. Phi Delta Kappan, 83(8), 642-643. Doi: 10.1177/003172170208300814

Carpenter, W. J., \& Hoffman, D. (1997). Learning by building: Design and construction in architectural education. New York: Van Nostrand Reinhold.

Christensen, L. R. (2008). The logic of practices of stigmergy. Proceedings of the ACM 2008 Conference on Computer Supported Cooperative Work - CSCW 08, 559-568.

doi:10.1145/1460563.1460652.

Cohen, J. (1998). Statistical power analysis for the behavioural sciences, Lawrence Erlbaum Associates. 
Cohen, J. (1988). Statistical power analysis for the behavioural sciences (2nd ed.). USA: Lawrence Earlbaum Associates.

Crinson, M., \& Lubbock, J. (1994). Architecture--art or profession?: Three hundred years of architectural education in Britain. Manchester, UK: Manchester University Press.

Demirbaş, O., \& Demirkan, H. (2003). Focus on architectural design process through learning styles. Design Studies, 24(5), 437-456. doi:10.1016/s0142-694x(03)00013-9.

Felicia, Patrick. (2011). Handbook of research on improving learning and motivation through educational games: Multidisciplinary approaches. Hershey PA: Information Science Reference.

Fox, J., \& Batholomae, S. (1999). Student learning style and educational outcomes. Financial Services Review 8(4), 235-251.

Gore, N. (2004). Craft and innovation: Serious play and the direct experience of the real. Journal of Architectural Education, 58(1), 39-44. doi: 10.1162/1046488041578211.

Historic England. (2008). Conservation principles, policies and guidance. Historic England. Jacobs, D. (1970). Master builders of the middle ages. London: Cassell.

Kolb, D. (1984). Experiential learning: Experience as the source of learning and development. Englewood Cliffs, NJ: Prentice Hall.

Kolb, D. A., Boyatzis, R. E., \& Mainemelis, C. (2000). Experiential learning theory: Previous research and new direction. NJ: Lawrence Erlbaum.

Kvan, T., \& Yunyan. J. (2005). Students learning styles and their correlation with academic performance in architectural design studio. Design Studies 26(1): 19-34. doi:10.5353/th_b3021883.

Lewin, K. (1948). Resolving social conflicts: Selected papers on group dynamics. New York: Harper \& Row. 
Morgan, M. H. (1914). The ten books on architecture. Harvard University Press.

Ousterhout, R. G. (2008). Master builders of Byzantium. Philadelphia: University of Pennsylvania Museum of Archaeology and Anthropology.

Prince, M. (2004). Does active learning work? A review of the research. Journal of Engineering Education. 93(3): 223-221

Roberts, A. (2006). Cognitive styles and student progression in architectural design education. Design Studies. 27(2): 167-81. doi:10.1016/j.destud.2005.07.001.

Royal Institute of British Architects. (2011-2015). Education statistics 2011-2015. London: Royal Institute of British Architects. (Compendium of annual reports from 2011 to 2015. 2011 report also captures information from 2007-2010).

Royal Institute of British Architects. (2013). Plan of work 2013. London: Royal Institute of British Architects.

Royal Institute of British Architects. (2014). RIBA procedures for validation and validation requirements. London: Royal Institute of British Architects.

Salama, A., O’Reilly, W. \& Noschis, K. (2002). Architectural education today: Cross-cultural perspectives. Lusanne: Comportements.

Salama, A., Delivering theory courses in architecture : inquiry based, active, and experiential learning integrated, International Journal of Architectural Research 4 (2-3), 2010, 278-295, ISSN 1938-7806

Schon, D. (1987). Educating the reflective practitioner: Toward a new design for teaching and learning in the professions. San-Francisco: Jossey Bass.

Sitkin, S. B. (1992). Learning through failure: The strategy of small losses. Austin: Dept. of Management. 
This is the final post-peer-review version of 'Experiential learning with building craft in the architectural design studio: A pilot study exploring its implications for built heritage in the UK.'. It is published in: Elsevier Thinking Skills and Creativity Volume 32, June 2019, Pages 102-113. DOI: 10.1016/j.tsc.2019.05.003

Thiel D., Class in construction: London building workers, dirty work and physical cultures, British Journal of Sociology 58 (2), 2007, 227-251, DOI:10.1111/j.1468-4446.2007.00149.x Vitruvius. (30-15 BC). De architectura (on architecture): The ten books on architecture, Vol. 1 of 10.

Webster, H., Facilitating critically reflective learning: excavating the role of the design tutor in architectural education, Art, Design \& Communication in Higher Education 2 (3), 2004, 101-111, ISSN 1474-273X

Wieringa, R. (2004). Debunking vitruvius. The GRAAL project. The Netherlands: University of Twente.

\section{Availability of data}

Copies of the design test survey and design drawing mark-ups from both control group and test group student participants (i.e. 'the raw design data') can be electronically issued upon request. 